\title{
REKAMAN TSUNAMI DI PESISIR BARAT ACEH: SEBUAH LAPORAN AWAL DAN PROSPEK PENELITIANNYA
}

\author{
Tsunami Record in Western Coast of Aceh: A Preleminary report and Future \\ Research Opportunities
}

\author{
Taufiqurrahman Setiawan', Aswan ${ }^{2}$, Nenggih Susilowati ${ }^{1}$, Andi Irfan Syam ${ }^{3}$, Anton Ferdianto $^{4}$, \\ Anggun Ibowo Saputra ${ }^{5}$, Dwi Wahyudi ${ }^{5}$, Deni Adreian ${ }^{5}$, Muhammad Bahrum ${ }^{5}$, Primawan ${ }^{1}$, dan \\ Sopingi Silalahi ${ }^{1}$ \\ ${ }^{1}$ Balai Arkeologi Sumatera Utara, \\ Jalan Seroja Raya Gg, Arkeologi No. 1, Tanjung Selamat, Medan Sumatera Utara 20134 \\ ${ }^{2}$ Program Studi Teknik Geologi, Fakultas Ilmu dan Teknik Kebumian, Institut Teknologi Bandung, \\ Jalan Ganesa No.10, Lb. Siliwangi, Kecamatan Coblong, Kota Bandung, Jawa Barat 40132 \\ ${ }^{3}$ Balai Pelestarian Cagar Budaya Banda Aceh, \\ Jalan Meulaboh - Banda Aceh Km 7,5, Rima Jeune, Peukan Bada, Kabupaten Aceh Besar, Aceh 23232 \\ ${ }^{4}$ Balai Arkeologi Jawa Barat, \\ Jalan Cinunuk KM. 17, Cileunyi, Cimekar, Cileunyi, Bandung, Jawa Barat 40623 \\ ${ }^{5}$ Jurusan Arkeologi, Fakultas Ilmu Budaya, Universitas Jambi, \\ Jalan Raya Jambi-Muara Bulian, KM.15 Mendalo Indah, Muaro Jambi, Jambi, 36122 \\ E-mail: taufiqurrahman.setiawan@kemdikbud.go.id
}

\begin{abstract}
The 26 December 2004 tsunami was one of the major natural disasters to have occurred in the Western Coast of Aceh. This disaster is not the first to occur in this region. The results of research in the Gua Ek Leunthie Cave have found evidence of at least 11 tsunamis since 7,400 years ago. One of the new data related to this tsunami was found in soil stratigraphic records in Gua Mabitce Cave. This stratigraphy shows the results of the sedimentation process by fluids that occur instantaneously which can be caused by storms or tsunamis. This stratigraphic layer is in context with the cultural remains of preneolithic, such as the Sumatralith, flakes, bone ekofacts, and shells. Currently, an absolute chronology regarding this matter has not been obtained because the date sample cannot be analyzed. Apart from Gua Mabitce Cave, the results of surveys conducted in 2018 and 2019 have also found Gua Tuandigedong Cave and Gua Paroy Indah Cave which have wide spatial dimensions, thick floor sediments, and the mouth of the cave overlooks the Indian Ocean. These two locations may also have stratigraphic layers associated with the tsunami and possibly their cultural context
\end{abstract}

Keywords: Tsunami, Western Coast of Aceh, Cave, Stratigraphy

\begin{abstract}
Abstrak
Tsunami 26 Desember 2004 merupakan salah satu bencanaalam yang besar yang pernah terjadi di wilayah Pesisir Barat Aceh. Bencana tersebut bukanlah yang pertama kali terjadi pada wilayah tersebut. Hasil penelitian di Gua Ek Leunthie telah menemukan bukti terjadinya minimal 11 kali tsunami sejak 7.400 tahun yang lalu. Salah satu data baru terkait tsunami ini ditemukan rekaman stratigrafi tanah di Gua Mabitce. Pada stratigrafi ditunjukkan adanya hasil proses sedimentasi oleh fluida yang berlangsung secara seketika yang dapat disebabkan oleh badai atau tsunami. Lapisan stratigrafi tersebut berkonteks dengan tinggalan budaya preneolitik, seperti kapak batu sumatralith, serpih batu, ekofak tulang, serta cangkang kerang. Saat ini, kronologi absolut terkait hal ini belum diperoleh karena sampel pertanggalan belum dapat teranalisis. Selain Gua Mabitce, hasil survey yang dilakukan pada tahun 2018 dan 2019 juga telah menemukan Gua Tuandigedong dan Gua Paroy Indah yang memiliki dimensi ruang luas, sedimen lantai tebal, dan mulut gua menghadap ke Samudra Hindia. Dua lokasi ini
\end{abstract}


kemungkinan juga memiliki lapisan stratigrafi terkait tsunami dan dan kemungkinan konteks budayanya

Kata kunci: Tsunami, Pesisir Barat Aceh, Cua, Stratigrafi

\section{PENDAHULUAN}

Tsunami Aceh tanggal 26 Desember 2004 adalah salah satu tsunami terbesar dan paling mematikan dalam sejarah manusia. Tsunami besar tersebut mengakibatkan hancurnya berbagai objek fisik dan budaya yang diterjangnya. Kerusakan yang terjadi juga beragam, bergantung pada kondisi bentukan lansekap dan arah arus tsunaminya. Istilah tsunami berasal dari bahasa Jepang, tsu (pelabuhan) dan nami (gelombang). Istilah tersebut digunakan karena melihat fenomena resonansi gelombang yang berkembang setelah terjadi gempa bumi yang berpusat di laut. Tsunami adalah gelombang, atau serangkaian gelombang dalam kereta gelombang, yang dihasilkan oleh perpindahan kolom air secara tiba-tiba dan vertikal. Perpindahan ini dapat disebabkan oleh aktivitas seismik, ledakan vulkanisme, tanah longsor di atas atau di bawah air, dampak asteroid, atau fenomena meteorologi tertentu. Gelombang ini dapat dihasilkan di lautan, teluk, danau, atau waduk (Bryant 2014, 3).

Pengaruh tsunami tidak hanya menghilangkan objek-objek yang diterjangkan namun juga dapat mengubah geomorfologinya. Perubahan tersebut karena ketika tsunami terjadi cukup banyak sedimen yang dilintasinya dapat tertransportasi. Tsunami besar adalah krisis geomorfik utama, karena menyiratkan erosi yang luas, pengangkutan sedimen dan pengendapan dalam beberapa menit dan lebih dari ratusan kilometer pantai. Dampak geomorfologis dari tsunami dibuktikan oleh erosi pantai (beberapa pantai hampir menghilang); penghancuran rintangan pasir yang melindungi laguna atau di muara sungai, banyak erosi tebing, erosi dasar tepi sungai, jejak benturan besar di lereng. Jejak erosi tsunami mengakibatkan mundurnya garis pantai hingga ratusan meter (Paris et al. 2009, 61). Selain aspek fisik tersebut, tsunami juga berimbas pada budaya di wilayah tersebut. Bencana tersebut dapat mengakibatkan putusnya siklus budaya. Fase hunian-tidak dihuni (hiatus)-hunian kembali - dan seterusnya mungkin sekali terjadi yang kemudian dapat memunculkan strategi adaptasi baru yang harus dilakukan maupun penghuni baru yang datang kemudian mengokupasi wilayah tersebut.

Selain tsunami yang terjadi pada tahun 2004, pesisir barat Aceh ternyata telah mengalami bencana tersebut sejak 7.400 tahun yang lalu. Hal tersebut diungkapkan oleh Rubin, et.al $(2012,6)$ dalam 'Highly variable recurrence of tsunami in the 7.400 years before the 2004 Indian Ocean tsunami' yang merupakan hasil penelitian di Gua Ek Leuntie di Lhoong, Aceh Besar. Hasil penelitian di lokasi tersebut menunjukkan bahwa telah terjadi minimal 11 kali tsunami purba sejak 7.400-2.900 tahun yang lalu (tyl) dengan interval rata-rata 450 tahun. Untuk kurun waktu setelah 2.000 tyl telah terjadi beberapa kali juga tsunami juga, tetapi tidak dapat teridentifikasi dengan jelas karena lapisannya sudah banyak terganggu (uncomformity) Hasil tersebut diperoleh dari hasil pertanggalan radiokarbon dan pertanggalan sedimen dari enam buah kotak ekskavasi 
yang dilakukan pada bagian paling dalam dari gua ini. Namun demikian, gambaran terkait aspek budaya pada penelitian tersebut tidak ditemukan.

Pada penelitian lain yang dilakukan oleh Sieh et.al (2015) yang dilakukan di Lhok Cut dan Lubhok, Aceh menemukan adanya endapan tsunami yang terjadi pada $1.344 \pm 3 \mathrm{M}$. Berbeda dengan penelitian di Gua Ek Leunthie, penelitian ini dilakukan pada salah satu situs terbuka. Pada lokasi ini ditemukan bukti adanya hunian yang berlangsung sejak 1.240 M hingga kemudian mengalami bencana tsunami pada endapan tsunami tersebut. Sedimen tsunami yang ditemukan pada lokasi tersebut ditunjukkan dengan adanya lapisan sedimen yang biasa ditemukan di dasar laut dan ditemukan di atas lapisan yang mengandung bukti arkeologis.

Berdasarkan hasil penelitian tersebut memberikan gambaran bahwa gua-gua yang berada di Pesisir Barat Aceh memiliki potensi menyimpan rekaman data tsunami yang pernah terjadi di wilayah tersebut. Dalam kajian arkeologi, gua juga merupakan salah satu objek yang dapat menyimpan data arkeologi hingga ribuan tahun, mengingat gua merupakan salah satu lokasi yang dipilih untuk dijadikan lokasi hunian pada masa lalu. Oleh karena itu, gambaran terkait permasalahan yang muncul dari penelitian di Gua Ek Leunthie dapat dijawab jika dua aspek tersebut ditemukan dalam satu lokasi.

Gua Mabitce merupakan salah satu lokasi gua yang dipilih untuk diteliti oleh Balai Arkeologi Sumatera Utara pada tahun 2019. Pada lokasi ini ditemukan adanya bukti arkeologis terkait pemanfaatan lokasi ini sebagai tempat hunian. Pada ekskavasi yang dilakukan pada lokasi tersebut ditemukan bukti-bukti arkeologis yang menunjukkan bahwa Gua Mabitce merupakan lokasi hunian pada masa lalu dengan ciri pendukung budaya Hoabinhian. Hal itu dibuktikan cukup banyaknya ditemukan kapak batu sumatralith, serpih, dan ekofak-ekofak fauna. Data arkeologis tersebut ditemukan pada lapisan stratigrafi atas hingga bawah (Setiawan et al. 2020).

Terkait dengan informasi gua dan rekaman tsunami di pesisir barat Aceh, mulut Gua Mabitce yang menghadap langsung ke arah samudera memungkinkan gelombang tsunami dapat masuk hingga ruangan gua. Keberadaannya gua yang berada pada lereng bawah tebing kemiringan hampir $90^{\circ}$ menjadikan lokasi ini sebagai barrier alam yang menjadi zona akhir gelombang tsunami. Kondisi inilah yang kemudian memungkinan sedimen yang terbawa gelombang tsunami dapat terdeposisi dalam celah-celah yang ada di tebing tersebut, termasuk Gua Mabitce. Apakah pada lokasi ini ditemukan juga bukti adanya potensi keberadaan data tsunami seperti yang ditemukan di Ek Leunthie? Permasalahan inilah yang akan coba dibahas dalam tulisan ini dengan menganalisis data stratigrafi yang ditemukan pada kotak ekskavasi. Selain itu, bagaimana prospek penelitian ke depan yang dapat membantu merekonstruksi aspek arkeologi dan kebencanaan di Pesisir Barat Aceh?

\section{PEMBAHASAN}

\section{Rekaman Tsunami Gua Mabitce}

Gua Mabitce berada di Gampong Deahmamplam, Kecamatan Leupung, Kabupaten Aceh Besar (5,402038 ${ }^{\circ}$ LU dan 95, $257909^{0}$ BT; UTM 46N 750204,32 
597569,56). Gua ini memiliki lorong dalam berbentuk huruf L dengan tinggi ruangan 17,4 m dengan lebar lorong antara 10-11,5 m. (Setiawan 2020, 33-34; lihat gambar 1). Ekskavasi Gua Mabitce membuka lima buah kotak eksksvasi yang menemukan adanya bukti arkeologis dari lapisan atas hingga bawah. Pada ekskavasi tersebut diketahui bahwa sedimen Gua Mabitce mencapai $180 \mathrm{~cm}$ dan setidaknya terdapat 10 lapisan stratigrafi. Selain temuan data arkeologis, salah satu data menarik yang ditemukan adalah adanya lapisan stratigrafi yang diduga merupakan lapisan stratigrafi tsunami (lihat gambar 2). Analisis stratigrafi terkait hal ini dilakukan pada dua lapisan stratigrafi pada dua kotak ekskavasi yang saling berdekatan, yaitu kotak S1T2 dan S3T1. Dugaan ini juga dipengaruhi oleh informasi terkait dampak tsunami Aceh 26 Desember 2004 di wilayah Leupung yang cukup besar. Hasil penelitian Paris et.al $(2009,61)$ menyebutkan telah mengakibatkan mundurnya garis pantai di wilayah Leupung mulai $60-150 \mathrm{~m}$ dengan tinggi gelombang $10-20 \mathrm{~m}$.

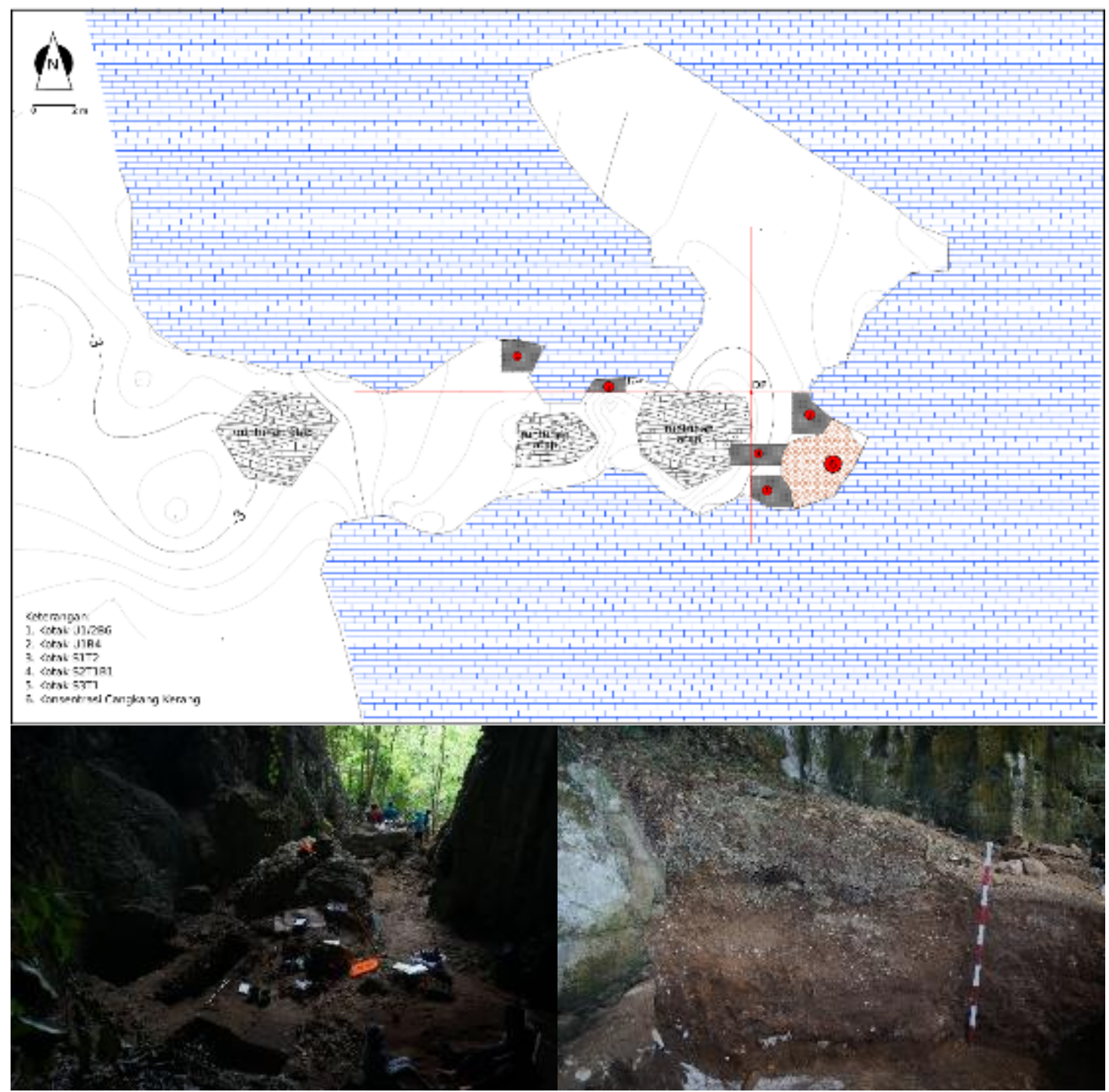

Gambar 1. Denah kotak ekskavasi Gua Mabitce tahun 2019 (atas); Ruang dalam Gua Mabitce (kiri bawah); dan gambaran stratigrafi salah satu kotak ekskavasi (kanan bawah)

(Sumber: Dokumen Balai Arkeologi Sumatera Utara, 2019). 
Pengamatan stratigrafi dan tafonomi pada kotak S1T2 dan S3T1 dilakukan karena bagian konsentrasi kerang yang berada pada dinding timur gua dan menjadi bagian dari kedua kotak ekskavasi tersebut. Pengamatan geologi yang dilakukan meliputi pengamatan stratigrafi, sedimentologi dan paleontologi fosil makro moluska. Untuk analisis tafonomi moluska pada penelitian ini, dibahas pada setiap lapisan yang mengandung cangkang moluska pada masing-masing kotak. Secara umum lapisan stratigrafi pada kedua kotak ekskavasi tersebut gambar 2 dan tabel 1.

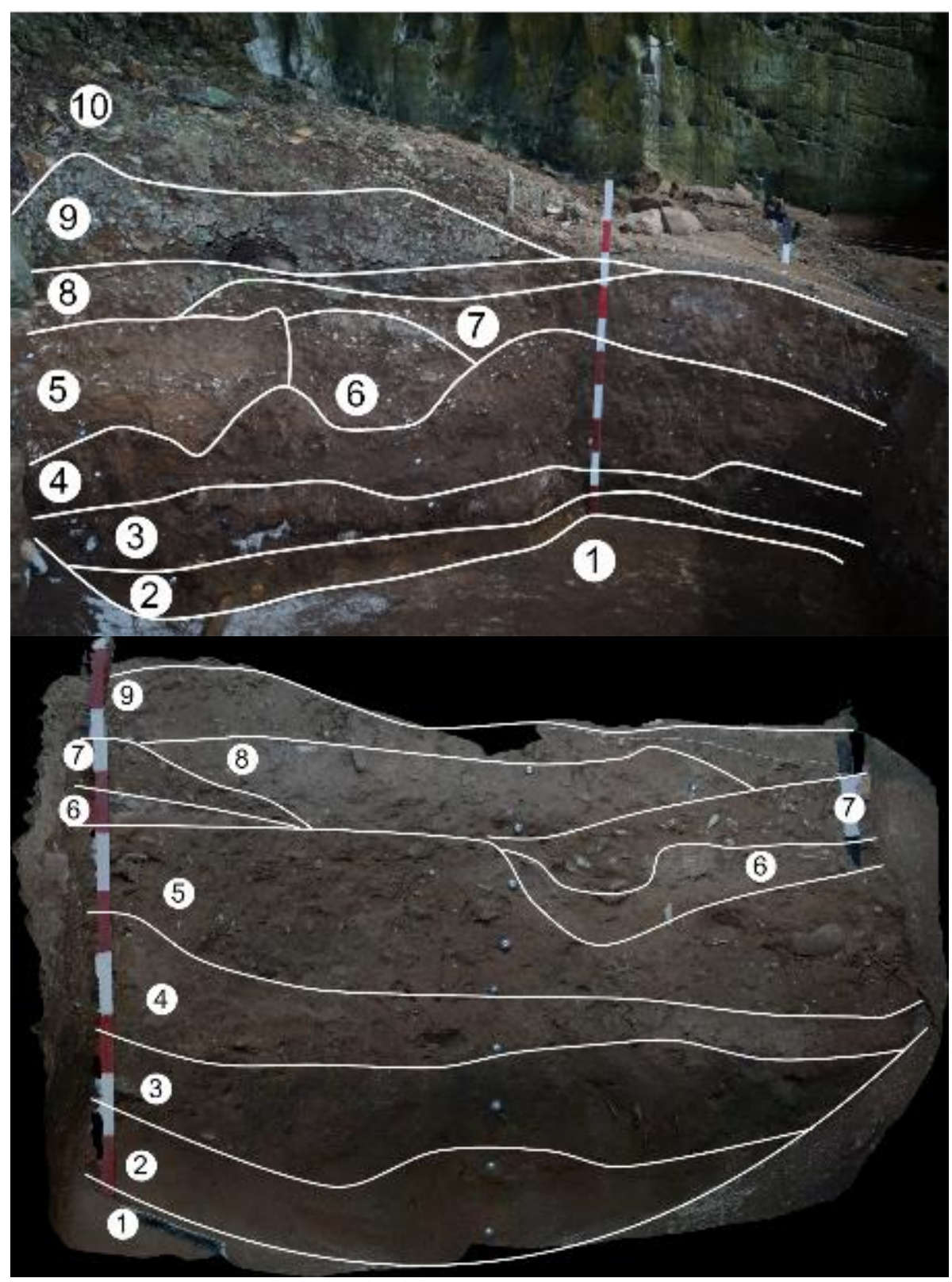

Gambar 2. Kotak S1T2 terdapat 10 lapisan batuan dan beberapa diantaranya mengandung cangkang moluska yang melimpah (atas) dan sketsa stratigrafi dinding timur Kotak S3T1 dimana terdapat 9 lapisan batuan dan beberapa diantaranya mengandung cangkang moluska (bawah). (Sumber: Dokumen Balai Arkeologi Sumatera Utara, 2019; digambar oleh Aswan, 2019; modifikasi Taufiqurrahman Setiawan, 2020). 
Tabel 1. Deskripsi Lapisan Stratigrafi Kotak S1T2 dan S3T1

\begin{tabular}{|c|c|c|}
\hline Lapisan & S3T1 & S1T2 \\
\hline 1 & Lapisan dasar/ bedrock (batugamping dasar gua). & Lapisan dasar/bedrock (batugamping dasar gua) \\
\hline 2 & $\begin{array}{l}\text { Batupasir halus lempungan berwarna coklat terang kemerahan dan } \\
\text { bersifat lepas-lepas }\end{array}$ & $\begin{array}{l}\text { Batupasir halus lempungan berwarna coklat terang dan bergradasi ke arah atas menjadi } \\
\text { coklat gelap, bersifat lepas-lepas dan terdapat struktur sedimen laminasi bersilang } \\
\text { (crosslamination); }\end{array}$ \\
\hline 3 & $\begin{array}{l}\text { Batupasir halus lempungan berwarna coklat gelap bersifat lepas-lepas } \\
\text { terdapat fragmen batugamping berasal dari lantai gua }\end{array}$ & $\begin{array}{l}\text { Batupasir halus berwarna coklat, lebih keras daripada lapisan "lapisan 2" dan terdapat } \\
\text { struktur sedimen laminasi bersilang (crosslamination) }\end{array}$ \\
\hline 4 & $\begin{array}{l}\text { Batupasir halus berwarna coklat terang dan bersifat lepas-lepas, } \\
\text { terdapat sedikit Brotia sp., Batissa sp. yang masih setangkup, fragmen } \\
\text { hematit dan pecahan pangkasan dari batuan volkanik yang menyudut }\end{array}$ & $\begin{array}{l}\text { Batupasir halus-sedang berwarna coklat, bersifat lepas-lepas, perlapisan bersilang } \\
\text { (crossbedding); }\end{array}$ \\
\hline 5 & $\begin{array}{l}\text { Batupasir halus lempungan berwarna coklat gelap bersifat lepas-lepas, } \\
\text { terdapat Brotia sp. (dalam jumlah yang lebih banyak dibandingkan } \\
\text { lapisan 4), Batissa sp. dan Neritina sp. serta pecahan tulang. }\end{array}$ & $\begin{array}{l}\text { Batupasir halus berwarna coklat terang dan bagian atasnya mengandung cangkang } \\
\text { Brotia sp. yang sangat melimpah }\end{array}$ \\
\hline 6 & $\begin{array}{l}\text { Batupasir halus berwarna abu-abu terang dan bersifat lepas-lepas, } \\
\text { berupa lapisan bekas abu perapian, terdapat Batissa sp., Brotia sp. dan } \\
\text { fragmen batugamping. }\end{array}$ & $\begin{array}{l}\text { Lensa Batugamping coquina (hampir seluruhnya terdiri dari pecahan cangkang } \\
\text { moluska) berwarna abu-abu }\end{array}$ \\
\hline 7 & $\begin{array}{l}\text { Batupasir halus lempungan berwarna coklat gelap dan bersifat lepas- } \\
\text { lepas, Brotia sp. sangat melimpah dan terdapat fragmen Batissa sp. }\end{array}$ & $\begin{array}{l}\text { Batupasir halus lempungan berwarna coklat keabuan sampai coklat gelap, bersifat } \\
\text { lepas-lepas, mengandung Brotia sp. yang melimpah dan sedikit Neritina sp }\end{array}$ \\
\hline 8 & $\begin{array}{l}\text { Batupasir halus berwarna abu-abu terang dan bersifat lepas-lepas, } \\
\text { terdapat Brotia sp. (jumlahnya lebih sedikit dibandingkan yang } \\
\text { terdapat pada lapisan } 7 \text { dibawahnya) dan Neritina sp. }\end{array}$ & $\begin{array}{l}\text { Batupasir halus berwarna coklat terang dan bersifat lepas-lepas, mengandung cangkang } \\
\text { Brotia sp. yang melimpah }\end{array}$ \\
\hline 9 & Batupasir halus lempungan berwarna coklat dan bersifat lepas-lepas. & $\begin{array}{l}\text { Brotia coquina (Batugamping coquina terdiri dari cangkang Brotia sp. yang sangat } \\
\text { melimpah), mengandung cangkang Brotia sp. yg sangat melimpah dengan sedikit } \\
\text { Neritina sp., sangat keras akibat proses sementasi dari hasil pelarutan gua }\end{array}$ \\
\hline 10 & & $\begin{array}{l}\text { Batissa coquina (Batugamping coquina terdiri dari cangkang Batissa sp. yang sangat } \\
\text { melimpah) mengandung cangkang Batissa sp. yg sangat melimpah dan terdapat } \\
\text { Telescopium sp sangat keras akibat proses sementasi dari hasil pelarutan gua dengan } \\
\text { permukaan lapisan yang kasar, ketebalan lapisan sekitar } 1 \mathrm{~m} \text { dengan permukaan yang } \\
\text { tidak rata }\end{array}$ \\
\hline
\end{tabular}


Analisis tafonomi moluska yang terdapat pada dinding timur kotak S3T1 menunjukkan bahwa pada lapisan 4 terdapat Batissa sp. (1 spesimen) yang masih setangkup dan Brotia sp. (1 spesimen dengan posisi sumbu panjang hampir horisontal) pada lapisan batupasir halus berwarna coklat terang di atas lapisan paleosoil (lapisan 5). Pada lapisan 5 ini Brotia sp. (dalam jumlah yang lebih banyak dibandingkan pada lapisan 4) dengan beberapa posisi sumbu panjangnya tegak lurus terhadap bidang horisontal, pecahan Batissa sp. (1 spesimen) dan Neritina sp. (1 spesimen), serta pecahan tulang. Lapisan 5 berupa batupasir halus lempungan berwarna coklat gelap.

Lapisan 4 dan lapisan 5 berdasarkan karakteristik batuan dan tafonomi moluskanya diperkirakan merupakan endapan akibat satu kali kejadian yang tiba-tiba (tsunami atau badai). Lapisan 4 adalah bagian endapan yang masih segar (berwarna coklat terang) karena posisinya di bagian bawah endapan, sedangkan lapisan 5 merupakan bagian atas endapan yang sudah melapuk (berwarna coklat gelap) karena kontak dengan udara luar. Energi gelombang diperkirakan awalnya tidak terlalu kuat yang mengendapkan lapisan 4, ditandai dengan kehadiran sedikit Brotia sp. dan Batissa sp. yang masih setangkup. Ketika gelombang semakin kuat diendapkan lapisan 5 yang ditandai oleh kehadiran pecahan Batissa sp. dan Brotia sp. yang melimpah dengan posisi dan penyebaran yang acak (tidak beraturan). Interpretasi yang sama juga untuk lapisan 6 dan lapisan 7. Pengamatan tafonomi moluska menunjukkan bahwa lapisan 6 dan lapisan 7 diendapkan dengan arus yang awalnya sangat kuat (lapisan 6), kemudian berkurang kekuatannya yang kemudian mengendapkan lapisan 7. Lapisan 8 dan lapisan 9 juga diinterpretasikan seperti lapisan-lapisan di bawahnya. Lapisan 8 ditafsirkan sebagai endapan yang masih segar (berwarna abu-abu terang) dan lapisan 9 ditafsirkan sebagai hasil pelapukannya (berwarna coklat). Tafonomi moluska yang terdapat pada lapisan 8 menunjukkan posisi sumbu panjang Brotia sp. yang semua relatif sejajar dengan bidang horisontal. Posisi penyebaran cangkang-cangkang Brotia sp. yang acak tidak beraturan diperkirakan akibat arus kuat yang mengendapkannya secara tiba-tiba. Pada lapisan 9 tidak ditemukan cangkang moluska yang bersifat insitu, hal ini diperkirakan akibat zona pelapukan yang masih tipis yang berada dekat permukaan saja. Lapisan 9 ini diperkirakan hasil pengendapan akibat gelombang balik ke arah luar gua setelah lapisan 8 diendapkan.

Analisis tafonomi moluska yang terdapat pada dinding timur Kotak S1T2 adalah pada lapisan 4 terdapat beberapa cangkang moluska Brotia sp. yang berjajar, sumbu panjangnya sejajar dengan orientasi struktur sedimen perlapisan bersilang. Hal ini mengindikasikan bahwa paling tidak cangkang moluska yang terdapat pada lapisan 4 adalah bersifat insitu (diendapkan dengan pengaruh arus air) atau bukan produk yang sudah dipindahkan oleh organisme atau manusia. Lapisan 5, 6 dan lapisan 7 diperkirakan merupakan endapan akibat satu kali kejadian yang tiba-tiba (tsunami atau badai). Pengamatan tafonomi moluska pada lapisan 5 dan lapisan 7 menunjukkan pengendapan sedimen dengan arus yang sangat kuat yang mengendapkan lapisan 5, kemudian pada waktu sudah berkurang kekuatannya lalu mengendapkan lapisan 7. Hal ini diindikasikan dengan terdapatnya kumpulan Brotia sp. pada lapisan 5 yang posisi 
sumbu panjangnya kedudukannya acak yang ditunjukkan dengan adanya beberapa spesimen sejajar bidang horisontal dan beberapa lainnya yang membentuk sudut dengan bidang horisontal, bahkan beberapa hampir tegak lurus terhadap bidang horizontal. Berbeda dengan di lapisan 5, pada lapisan 7 cangkang moluska Brotia sp. meskipun juga tersebar acak tetapi sumbu panjang nya semuanya sejajar dengan bidang horizontal. Lapisan 6 berdasarkan pengamatan tafonomi Brotia sp.yang acak dan tertanam dalam masa dasar material karbonat serta bentuknya yang menyerupai lensa dalam lapisan 5, maka diperkirakan lapisan 6 adalah fragmen batugamping coquina yang dibawa gelombang yang kuat ke gua dari tepi pantai.

Analisis tafonomi moluska pada lapisan 8 dan 9 menunjukkan bahwa Brotia sp. yang sangat melimpah pada lapisan ini cangkangnya saling bersentuhan rapat satu sama lain (hampir tidak ada butiran sedimen diantaranya) dan tersusun beraturan. Ciri tafonomi seperti ini menunjukkan adanya dua periode penumpukan Brotia sp. yang diperkirakan akibat aktivitas manusia yang hidup di gua dan menjadikan Brotia sp. sebagai bahan pangan. Batissa sp. yang sangat melimpah pada lapisan 10, menunjukkan kondisi cangkang yang relatif utuh dan masing-masing sudah tidak setangkup lagi. Batissa sp. yang sangat melimpah pada lapisan ini cangkangnya juga saling bersentuhan rapat satu sama lain (hampir tidak ada butiran sedimen diantaranya) dan tersusun beraturan saling menumpuk seperti piring (tidak ada yang saling membentuk sudut). Ciri tafonomi seperti ini, seperti juga Brottia sp. yang terdapat pada lapisan 8 dan 9 diperkirakan sebagai akibat aktivitas manusia yang menjadikan Batissa sp. sebagai bahan pangan.

Hasil pengamatan menunjukkan bahwa secara stratigrafi terdapat beberapa lapisan batuan yang berbeda baik pada kotak S3T1 dan kotak S1T2. Perbedaan lapisan ini ditunjukkan oleh perbedaan warna lapisan batuan dari gelap ke terang dan perbedaan kandungan dan tafonomi moluska serta besar butirnya. Adanya beberapa perlapisan batuan ini menunjukkan adanya beberapa kali periode pengendapan batuan pada lingkungan atau keadaan yang berbeda. Pada dinding kotak S1T2 bagian bawah (lapisan 2, 3 dan 4) terdapat struktur sedimen laminasi bersilang (crosslamination) dan perlapisan bersilang (crossbedding) yang menunjukkan adanya pengaruh fluida (air) pada waktu pengendapannya. Berkaitan dengan hal tersebut terdapat struktur sedimen perlapisan bersilang yang sumbu panjang cangkang moluska Brotia sp. sejajar dengan orientasi struktur sedimennya, sehingga dapat disimpulkan bahwa paling tidak cangkang moluska yang terdapat pada lapisan 4 adalah bersifat insitu atau bukan produk yang sudah dipindahkan oleh organisme.

Salah satu lapisan stratigrafi di Gua Mabitce teridentifikasi sebagai lapisan yang terbentuk karena bencana tsunami. Bukti arkeologis yang ditemukan menunjukkan ciri budaya yang sama yaitu hoabinhian. Hal itu dibuktikan dengan temuan-temuan artefak batu sumatralith, serpih, split-pebble, serta batu pukul yang ditemukan di atas maupun di bawah lapisan tsunami. Namun saat ini, kronologi absolut terjadinya tsunami yang terekam di Gua Mabitce belum dapat diketahui karena pertanggalan radiokarbon untuk lapisan tersebut belum dapat dilakukan. 
Temuan lapisan tsunami di Gua Mabitce didominasi oleh deposisi cangkang kerang dan sedimen hasil transportasi oleh air. Cangkang kerang teridentifikasi adalah Brottia sp yang memiliki habitat sungai berarus kuat. Hal ini memunculkan pertanyaan tentang lingkungan masa lalu di depan Gua Mabitce. Apakah di depan gua dahulu terdapat aliran sungai yang berarus kuat? Hal ini masih memerlukan pembuktian lebih lanjut dengan melakukan beberapa ekskavasi/pengeboran pada lingkungan di depan Gua Mabitce. Namun jika dikaitkan dengan mundurnya garis pantai karena pengaruh tsunami dan perubahan lingkungan pasca-tsunami, hal ini sangat mungkin terjadi.

\section{Prospek Penelitian Ke Depan}

Hasil survei gua dan ceruk pada tahun 2018 dan dilanjutkan pada tahun 2019 yang menemukan 12 lokasi gua. Namun hanya beberapa gua yang memungkinkan untuk diteliti lebih lanjut. Selain Gua Mabitce dan Gua Ek Leunthie, hasil analisis potensi pemanfaatan hunian dan penelitian yang menunjukkan adanya gua lain yang berpotensi untuk diteliti lebih lanjut yaitu Gua Tuandigedong (Setiawan 2020, 41).

Gua Tuandigedong terletak di Gampong Keutapang, Kecamatan Lhoong, Kabupaten Aceh Besar. Lokasi gua ini berada dekat dengan gua Ek Leunthie. Mulut gua berada tepat di pinggir Jalan Raya Banda Aceh-Meulaboh dan berada pada lereng bawah perbukitan Kars Lhoong. Gua yang berada pada koordinat 5.222188 LU dan 95.278012 BT (UTM 46N 752506.41 577681.77) memiliki morfologi ruang yang sangat luas dengan dua pintu menghadap ke selatan $\left(180^{\circ}\right)$ dengan permukaan lantai gua relatif datar dan kering. Intensitas pencahayaan dan sirkulasi udara sangat baik. Lokasi gua ini berada satu bukit dengan Gua Pari yang berada di selatannya. Gua ini juga berjarak $\pm 1 \mathrm{~km}$ dengan Krueng Lhoong yang berada di utaranya dan $\pm 2 \mathrm{~km}$ dari garis pantai sekarang di bagian baratnya. Saat ini, masyarakat memanfaatkan gua ini untuk pengambilan guano. Oleh karena itu, sebagian besar lantai gua pada bagian ruangan gua bagian dalam telah digali hingga batuan dasarnya terutama pada bagian belakang. Bagian yang masih relatif terjaga masih ditemukan pada bagian pintu masuk gua dan ruangan bagian selatan. Pada lokasi ini ditemukan cukup banyak manuport batu andesit yang mungkin berasal dari Krueng Lhoong yang berada di utaranya, namun belum ditemukan adanya artefak batu pada saat survei dilakukan. Temuan permukaan di gua ini adalah fragmen-fragmen tulang binatang (Setiawan 2020, 30-31)

\section{SIMPULAN}

Hasil penelitian Gua Mabitce menunjukkan adanya bukti rekaman bencana tsunami pada masa lalu yang terjadi di Pesisir Barat Aceh. Bukti arkeologis yang ditemukan menunjukkan pengaruh budaya Hoabinh. Budaya tersebut ditemukan pada lapisan budaya di bawah dan di atas lapisan tsunami di Gua Mabitce. Berdasarkan pertanggalan relatif pada situs-situs Hoabinh di Sumatra bagian utara, Gua Mabitce kemungkinan dihuni pada awal Holosen antara 7.000-5.000 tyl. Oleh karena itu, rekaman tsunami Gua Mabitce kemungkinan berasal dari rentang waktu tersebut. Pembuktian dengan pertanggalan absolut masih perlu dilakukan untuk mempertegas 
kronologi di Gua Mabitce. Penelitian lanjutan terkait aspek budaya dan bencana, di Pesisir Barat Aceh masih perlu dilakukan pada lokasi-lokasi lain. Dua pilihan yang mungkin dapat dilakukan adalah di Gua Tuandigedong dan Gua Paroi Indah. Kedua gua ini memiliki potensi untuk dijadikan lokasi hunian pada masa lalu serta kemungkinan adanya data tsunami yang terekam dalam lapisan stratigrafinya.

\section{DAFTAR PUSTAKA}

Bryant, Edward. 2014. Tsunami: The Underrated Hazard. Third Edit. Chicester: Springer and Praxis Publishing.

Paris, Raphaël, Patrick Wassmer, Junun Sartohadi, Franck Lavigne, Benjamin Barthomeuf, Emilie Desgages, Delphine Grancher, et al. 2009. "Geomorphology Tsunamis as Geomorphic Crises : Lessons from the December 26 , 2004 Tsunami in Lhok Nga , West Banda Aceh ( Sumatra , Indonesia )." Geomorphology 104 (12): 59-72. https://doi.org/10.1016/j.geomorph.2008.05.040.

Rubin, Charles M., Benjamin P. Horton, Kerry Sieh, Jessica E. Pilarczyk, Patrick Daly, Nazli Ismail, and Andrew C. Parnell. 2012. "Highly Variable Recurrence of Tsunami in the 7.400 Years before the 2004 Indian Ocean Tsunami." Nature Comunication, 2012. https://doi.org/10.1038/ncomms16019.

Setiawan, Taufiqurrahman. 2020. "Potensi Hunian Gua Dan Ceruk Di Kabupaten Aceh Besar.” Berkala Arkeologi 40 (1): 23-44. https://doi.org/10.30883/jba.v40i1.506.

Setiawan, Taufiqurrahman, Anton Ferdianto, Nenggih Susilowati, Aswan Aswan, Andi Irfan Syam, Anggun Ibowo Saputra, Dwi Wahyudi, et al. 2020. "Gua Mabitce: Data Baru Situs Hoabinh Di Sumatra Bagian Utara." AMERTA 38 (2): 115-28. https://doi.org/https://doi.org/10.24832/amt.v38i2.115-128.

Sieh, Kerry, Patrick Daly, E. Edwards McKinnon, Jessica E. Pilarczyk, Hong-Wei Chiang, Benjamin Horton, Charles M. Rubin, et al. 2015. "Penultimate Predecessors of the 2004 Indian Ocean Tsunami in Aceh, Sumatra: Stratigraphic, Archeological, and Historical Evidence." Journal of Geophysical Research: Solid Earth 120: 1-18. https://doi.org/10.1002/2014JB011538.

\section{HASIL DISKUSI}

\section{Pertanyaan}

1. Ary Sulistyo (TACB Kota Depok)

Nilai apa yang didapat dari hasil penelitian lingkungan yang telah dilakukan tersebut?

2. Candrian Attahiyyat (TACB DKI Jakarta)

Adakah masukan untuk pemerintah dalam mengambil kebijakan pembangunan kaitannya dengan hasil penelitian ini?

\section{Jawaban}

1. Dari hasil penelitian terlihat bahwa telah terjadi bahwa bencana dapat memutus siklus budaya dan pembawa budaya yaitu manusi karena efek yang ditimbulkan dari bencana tersebut. Ketika bencana berakhir suatu lokasi dapat dihuni kembali oleh pemukim yang sama namun juga tidak menutup kemungkinan adanya pemukim baru yang datang kemudian dan mengembangkan budaya mereka. 
Adaptasi manusia karena perubahan lingkungan juga dapat mempengaruhi adanya perubahan pada budaya karena aspek lingkungan juga merupakan faktor pendukung yang sangat berpengaruh pada aspek budaya. Kebudayaan baru akan muncul sebagai dampak adaptasi dengan lingkungan yang baru.

2. Hasil penelitian ini diharapkan dapat memberikan regulasi/kebijakan terkait keberadaan lokasi situs yang memiliki resiko rusak cukup besar karena berada pada radius $1 \mathrm{~km}$ dari Pabrik Semen Andalas yang berada di Lhoknga. Resiko kerusakan pada situs yang menyimpan data budaya masa lalu dan rekaman bencana yang mungkin akan kembali terulang di Pesisir Barat Aceh itu cukup besar. Oleh karena itu, Pemerintah diharapkan dapat meninjau kembali terkait wilayah operasi dari pabrik semen di Lhok Nga dan juga perlunya adanya zona konservasi terkait keberadaaan gua Mabitce dan gua-gua lain di wilayah kars Lhok Nga, dan Kars Leupung. 